\title{
Invited review: Metabolic challenges and adaptation during different functional stages of the mammary gland in dairy cows: Perspectives for sustainable milk production
}

\section{J. J. Gross* and R. M. Bruckmaier}

Veterinary Physiology, Vetsuisse Faculty, University of Bern, CH-3012 Bern, Switzerland

\section{ABSTRACT}

Milk production of dairy cows has increased markedly during recent decades and continues to increase further. The evolutionarily conserved direction of nutrients to the mammary gland immediately after calving provided the basis for successful selective breeding toward higher performance. Considerable variation in adaptive responses toward energy and nutrient shortages exists; however, this variation in adaptability recently gained interest for identifying more metabolically robust dairy cows. Metabolic challenges during periods of high milk production considerably affect the immune system, reproductive performance, and product quality as well as animal welfare. Moreover, growing consumer concerns need to be taken into consideration because the public perception of industrialized dairy cow farming, the high dependency on feed sources suitable for human nutrition, and the apparently abundant use of antibiotics may affect the sales of dairy products. Breeding for high yield continues, but the metabolic challenges increasingly come close to the adaptational limits of meeting the mammary gland's requirements. The aim of the present review is to elucidate metabolic challenges and adaptational limitations at different functional stages of the mammary gland in dairy cows. From the challenges and adaptational limitations, we derive perspectives for sustainable milk production. Based on previous research, we highlight the importance of metabolic plasticity in adaptation mechanisms at different functional stages of the mammary gland. Metabolic adaptation and plasticity change among developing, nonlactating, remodeling, and lactational stages of the mammary gland. A higher metabolic plasticity in early-lactating dairy cows could be indicative of resilience, and a high performance level without an extraordinary occurrence of health disorders can be achieved.

Received September 18, 2018.

Accepted December 24, 2018.

*Corresponding author: josef.gross@vetsuisse.unibe.ch
Key words: metabolic adaptation, transition period, mammary gland, dairy cow

\section{INTRODUCTION}

Mammals invest considerable energy and nutrient resources to establish and sustain gravidity to full term (Hayssen, 1993; Langer, 2008). Consequently, a high probability of offspring survival requires further maternal care after birth in the form of lactation. The availability of mammary gland secretion during lactation supports the development of the offspring in many ways, such as providing immunization and nutrition and strengthening mother-offspring bonding (Oftedal, 2012; Bruckmaier and Gross, 2017). The domestication of ruminants and breeding for milk production in dairy cows to levels far beyond the needs of their own offspring are essential for maintenance of human food security in terms of meat and milk production. The driving forces pushing dairy cow selection toward higher performance resulted in a continuous increase in milk production in recent decades (Akers, 2000; Capper et al., 2009). During the past $30 \mathrm{yr}$, milk production almost doubled in many countries worldwide (Capper et al., 2009; von Keyserlingk et al., 2013).

However, milk production challenges the metabolism and health of dairy cows. Although complex adaptation processes take place to enable the maintenance of the animals' energy and nutrient homeostasis, many individuals fail to successfully cope with the genetically imposed burden of meeting the requirements for the metabolically prioritized mammary gland in early lactation (Drackley, 1999; Ingvartsen, 2006; van Knegsel et al., 2014). Consequently, metabolic stress arises with various effects on the immune system, reproductive performance, milk yield, product quality, and the overall well-being of the dairy cow (Drackley et al., 2005; Bradford et al., 2015; Bruckmaier and Gross, 2017). In particular, public perception of industrialized dairy cow farming, the controversial discussion about ruminantderived greenhouse gas emissions, the high dependency on feed sources suitable for human nutrition, and the 
apparently abundant use of antibiotics do not support the reputation of modern dairy farming (Boogaard et al., 2011a,b; Cardoso et al., 2016). Public concerns must be taken seriously (Te Velde et al., 2002; Weary and von Keyserlingk, 2017), keeping in mind that the agricultural industry depends on the consumers who purchase the products. Awareness of ethical and animal welfare issues has increased, and customer concerns and perceptions have considerably shaped the way of agriculture (e.g., organic farming, banning of hormones and growth-promoting agents in livestock production in many countries; von Keyserlingk et al., 2013; Barkema et al., 2015; Weary et al., 2016). The market demand for dairy products depends on consumer acceptance, which generates income for dairy farmers (Weary and von Keyserlingk, 2017). An efficient and sustainable dairy business requires a serious and continuous rethinking of management practices (von Keyserlingk et al., 2013). However, cows adapt more or less successfully to metabolic challenges (Hachenberg et al., 2007; Kessel et al., 2008; Gross and Bruckmaier, 2015). Production diseases are not necessarily related to performance level, although the risk increases with higher performance (Fleischer et al., 2001; Ingvartsen et al., 2003; Mulligan and Doherty, 2008). Our recent research aimed at identifying more robust and resilient dairy cows revealed that adaptation response patterns are flexible at later lactational stages (Figure 1; Gross and Bruckmaier, 2015). This metabolic plasticity implies the extent to which a cow tolerates catabolic stages without developing health disorders (Gross and Bruckmaier, 2015; Bruckmaier and Gross, 2017).

The present review focuses on the mammary gland, which undergoes various endocrine and metabolic adaptations at different developmental and functional stages. Depending on the functional stage, current challenges that dairy cows are facing are revisited. Perspectives and potentials to counter the imposed challenges are addressed, with emphasis on the metabolic plasticity of the mammary gland in early-lactating dairy cows.

\section{CLASSICAL BREEDING STRATEGIES, ASSOCIATED RISKS FOR ANIMAL HEALTH, AND IMPORTANCE OF METABOLIC PLASTICITY}

The onset of lactation in dairy cows is characterized by a high priority in directing nutrients to the mammary gland (Figure 1; Bauman and Currie, 1980; Bell, 1995; Bruckmaier and Gross, 2017). Despite the presence of a negative energy balance (NEB), milk production is maintained and further increases until peak lactation (Figure 1; Gross et al., 2011a). Thus, the survival of the milk-fed offspring is ensured (Lefèvre et al., 2010; Oftedal, 2012). This highly genetically anchored mechanism enabled animal breeders to select for higher yielding dairy cows, in particular those with higher milk production in early lactation. The selection toward higher milk yield continues worldwide (Capper et al., 2009; von Keyserlingk et al., 2013). However, it is unclear to what extent metabolic priority of the lactating mammary gland is genetically determined or to what extent its expression can be manipulated by breeding. The question arises of how excessive nutrient partitioning can be avoided at the current high performance level.

Recent studies showed that overall lifetime performance and longevity must be improved to achieve more efficiency and sustainability in milk production (Hadley et al., 2006). Losses up to $15 \%$ due to culling occur during the rearing phase of animals before they actually start to produce milk (Wathes et al., 2008; Pritchard et al., 2013). Additionally, the metabolic status of dairy cows after calving clearly affects reproductive performance in terms of successfully establishing a new gravidity (Wathes, 2012; Rutherford et al., 2016).

The classical approach and aim of feeding animals according to their energy and nutrient requirements (e.g., Mertens and Dado, 1993; Sniffen et al., 1993) throughout all stages of the gestation-lactation cycle is not always possible (Overton and Waldron, 2004). Owing to the limited feed intake capacity and restrictions from the cow's side (e.g., limited capacity for glucose and lipid absorption, maintenance of rumen function), the actual requirements cannot be met by feeding and must be covered by a tremendous mobilization of body reserves (Bruckmaier and Gross, 2017; Han van der Kolk et al., 2017). Despite advances in animal nutrition and veterinary care (Drackley et al., 2006; Eastridge, 2006), dairy cows are still at a high risk of developing so-called production diseases, with the highest incidence rates coinciding with the greatest metabolic load during the energy deficiency following parturition (Ingvartsen et al., 2003; Mulligan and Doherty, 2008). On the other hand, dairy farmers are facing various challenges (e.g., economic pressure, consumer concerns and confidence, legislation, and so on). For economic reasons, farmers are often forced to optimize production costs and to limit expensive feed sources and concentrate supplementation.

It is well known that considerable biological variation in metabolic adaptation exists among individual animals, in particular during the transition from late gestation to early lactation accompanied by distinct levels of metabolic stress (Figure 1; Kessel et al., 2008; Gross and Bruckmaier, 2015). Metabolic robustness implies the successful adaptation to the lactational challenges after parturition irrespective of performance level. Excessive adaptation responses are undesirable 
in early lactation, whereas metabolic adaptation responses to environmental and metabolic stressors at later lactational stages have less detrimental effects on animal health. Milk yield may temporarily decline at a later lactational stage but can recover as soon as energy and nutrient supply meet the requirements of the mammary gland. Today, animal breeding and genetics have the tools to identify the genetic basis of phenotypic traits that can be annotated to defined genomic regions (Berry, 2018; Pryce et al., 2018). The disciplines of

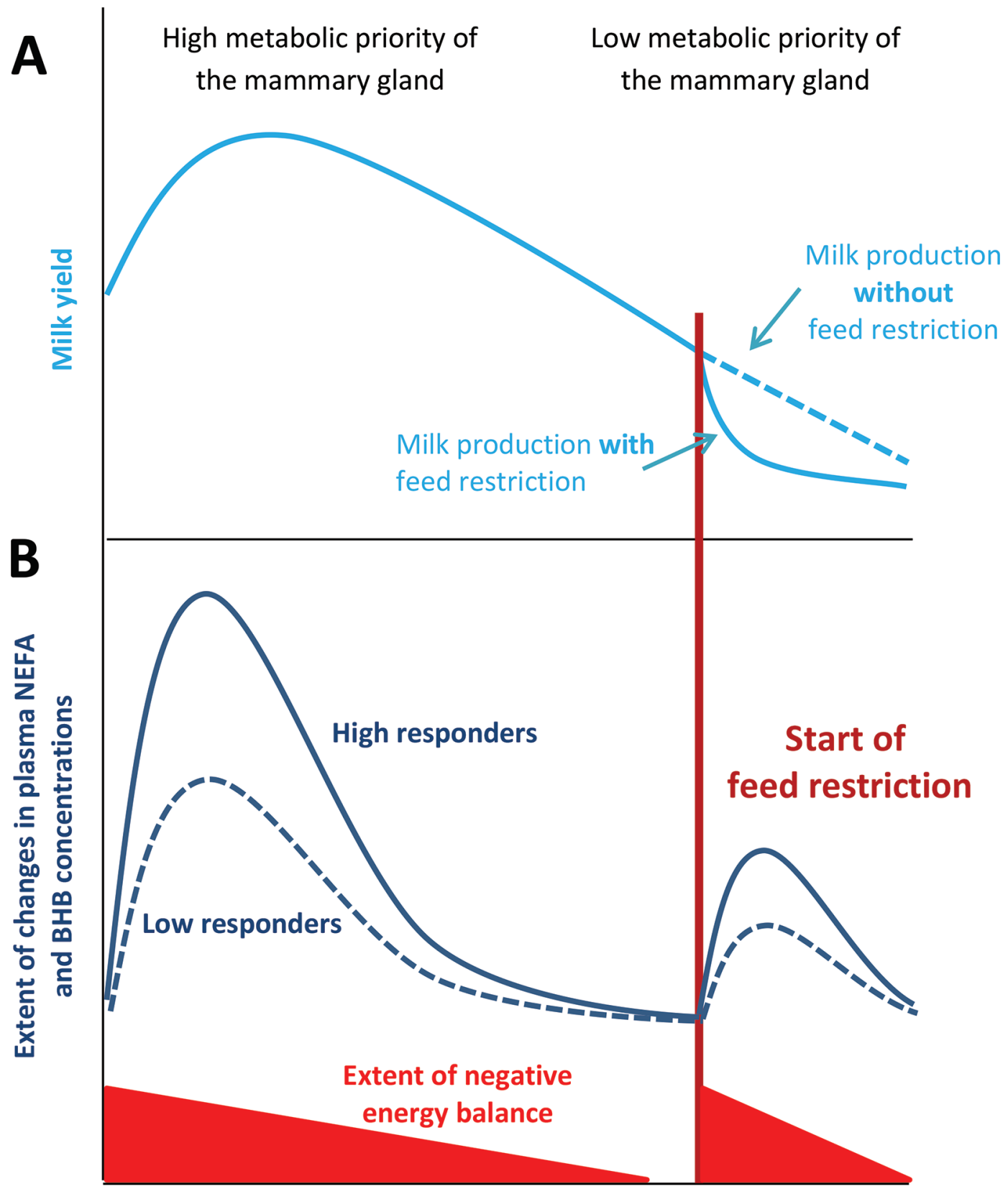

Parturition Early lactation

Mid lactation

Figure 1. Lactation curves in dairy cows exposed to negative energy balance in early lactation and feed restriction in mid lactation (A). In mid lactation, restricting energy and nutrient availability by approximately $50 \%$ resulted in a $<20 \%$ decline in cow milk yield. Individual differences in the adaptation responses to energy deficiency at 2 distinct stages of metabolic priority of the lactating mammary gland are characterized by changes in plasma nonesterified fatty acids (NEFA) and BHB concentrations of a high- and low-responding group (B). High (and low) responders were classified as cows with high (and low, respectively) plasma concentrations of NEFA and BHB during the negative energy balance in early lactation. Graphs are adapted from Gross et al. (2011a) and Gross and Bruckmaier (2015). 
animal physiology and nutrition can provide knowledge on the biological relevance and relationships among genetic factors and their phenotypic expression as well as the potential to manipulate them. International research on dairy cow physiology aims at understanding and predicting cows' ability to adapt to metabolic and immunological challenges. An innovative and ambitious approach to reducing metabolic stress implies shifting the period of reversible and smooth metabolic adaptations as observed at later lactational stages (Gross et al., 2011a,b; Gross and Bruckmaier, 2015). A greater metabolic plasticity at an earlier lactational stage could alleviate metabolic stress. The animal would be more flexible in terms of adjusting performance depending on the actual nutrient availability. Thus, the period of excessive metabolic adaptations during which most prominent health problems of dairy cows occur could be limited to a certain "tolerable" period of time. Concomitantly, the beneficial effects of established homeostatic mechanisms, which maintain more or less high performance but not at the costs of the animal's health, increasingly apply. Before metabolic plasticity can be targeted in breeding, a profound knowledge of the physiological adaptation mechanisms in dairy cows exposed to metabolic stressors is indispensable. The implementation of plasticity in dairy farming is inevitable to improve sustainability.

Different dairy breeds tolerate environmental and feeding changes to a different extent. Holstein dairy cows expressed a high metabolic load but maintained milk production quite well during exclusive herbage feeding (Zbinden et al., 2017), whereas Brown Swiss cows reduced milk yield on pasture without a considerable metabolic load (Frey et al., 2018). Testing cows at an individual level to predict metabolic adaptation implies that adaptation response is genetically anchored. Ha et al. $(2015,2017 b, c)$ showed that phenotypic expressions of the metabolites glucose, nonesterified fatty acids (NEFA), and BHB are associated with a differential expression of genes involved in robustness and resilience traits. The latest technologies such as nextgeneration sequencing and metabolomics allow a more comprehensive view on relevant pathways and potential candidate markers for selection (Loor, 2010; Huber et al., 2016; Ha et al., 2017a). Testing individual cows on farm might be desirable for prediction of metabolic adaptation. For instance, adrenal cortex reactivity was shown to be lower in dairy cows with a higher metabolic load during NEB in early lactation (Beerda et al., 2004; Gross et al., 2018b). However, individual differences in endocrine and metabolic adaptation had a greater influence on adrenal cortex responsiveness than did inherent individual genetic disposition (Gross et al., 2018b). Consequently, adrenocorticotropic hormone challenge tests have only a limited ability to extrapolate physiological responses onto other lactational stages.

This article elucidates the mechanisms of metabolic adaptation in growing heifers and adult dairy cows between successive lactations along with the effect on milk production. Feeding intensity and management clearly affect the metabolic adaptation processes during mammary gland development and remodeling as well as milk production later on.

\section{CONSEQUENCES OF FEEDING INTENSITY AND MANAGEMENT FOR MAMMARY GLAND DEVELOPMENT AND REMODELING}

Recently, ad libitum feeding of milk and milk replacer to calves in early life was recommended to stimulate mammary gland development and to achieve a better lifetime performance (Davis Rincker et al., 2011; Geiger et al., 2016). However, epigenetic effects caused by feeding level are assumed to be effective only in early life (Schäff et al., 2016; Kesser et al., 2017; Korst et al., 2017). Still, restricted prepubertal feeding is recommended to achieve a high degree of development of parenchymal structures and a low portion of adipocytes in the mammary gland, with direct effect on later lactational performance (Sejrsen and Purup, 1997; Purup et al., 2000). Excessive prepubertal heifer growth allows early breeding on one hand but also results in a high accumulation of fat in the mammary fat pad and only a poorly developed functional parenchyma (Sejrsen et al., 1982; Akers, 2017a,b).

During lactation, no further mammogenesis that might modulate milk production occurs in bovine species (Akers, 2017a,b; Davis, 2017). Although rearing in early life significantly affects growth and later performance (Kaufhold et al., 2000), adult cows may adapt differentially to successive lactations, with a clear effect of the dry period between (Gabai, 2003; Chen et al., 2016a,b). Drying off dairy cows initiates the process of mammary gland involution and redevelopment (Capuco et al., 1997; Capuco and Akers, 1999). During evolution, declining milk production after peak lactation pushed the calf to consume forage besides milk (Hayssen, 1993). The cessation of the dam's milk synthesis enables a renewal of mammary epithelial cells and the alveolar structure (Knight and Wilde, 1993; Capuco et al., 1997). Simultaneously, the spared energy and nutrients can be used for the exponentially growing fetus in late pregnancy. Dry period lengths of 6 to 8 wk have been established (Capuco and Akers, 1999; Grummer and Rastani, 2004). However, dry cows are subjected to several challenges. First, the risk of infection of the mammary gland is high in the days following dry-off (Rajala-Schultz et al., 2005; Ollier et al., 2015). 
Dietary composition changes are required so that cows do not excessively accumulate body fat when there is no energy demand for milk production (Beever, 2006; van Hoeij et al., 2017a,b). Otherwise, cows are at a high risk of developing ketosis and other production diseases after parturition due to enhanced body fat mobilization (Dann et al., 2006; Mann et al., 2016). Cows with a high prepartum BCS show lower DMI postpartum, which in turn exacerbates NEB and lipolysis of adipose tissue and favors the development of hepatic steatosis (Gerloff, 2000). Finally, cessation of milking does not generate a net income for the farmer. During recent years, milk production increased not only in early lactation but also at later lactational stages. Cows need to be dried off while still producing milk at a high level (Rajala-Schultz et al., 2005; Ollier et al., 2015). Considering the effect of poor dry cow management (e.g., failures BCS control, switching to dual-step feeding with a far-off and close-up transition diet), the loss of milk production, the potential of extended lactation periods, later insemination, and so on, the need for and length of the dry period are controversial (Grummer and Rastani, 2004; Pezeshki et al., 2010; Collier et al., 2012).

Omitting the dry period could be one strategy to waive antimicrobial teat injectors for dry-off and generally reduce the susceptibility to mastitis at this critical point. The major potentials of continuously milking cows without dry-off, however, are to avoid presumable and likely unavoidable emerging problems such as depression of DMI shortly before parturition or the risk of further weight gain in already overconditioned cows. The effect of dry period length modification on colostrum quality is addressed in a later section. Shortening the dry period length to 30 or $21 \mathrm{~d}$ or even omitting the dry period has benefits for metabolic adaptation in the lactation period following calving but also imposes new challenges on management (van Knegsel et al., 2013). Metabolic status was shown to be improved in early lactation in cows without a dry period but milk production was reduced concomitantly (Chen et al., 2015; van Hoeij et al., 2017a,b); however, effects of a 0-d dry period were less pronounced in a second year without previous drying off (Chen et al., 2016a,b). However, more attention must be paid to an adequate composition of the feed ration in mid to late lactation to avoid fattening low-yielding cows that are continuously milked (van Hoeij et al., 2017a,b). Although dietary changes had little effect on characteristics and persistency of the lactation curve, control of excessive BW gain during the ongoing lactation had positive effects on energy balance and metabolic status in the subsequent lactation period after calving (Chen et al., 2016a; van Hoeij et al., 2017a,b).

\section{NECESSITY FOR IMMEDIATE COLOSTRUM AVAILABILITY AND CONSEQUENCES FOR ENDOCRINE AND METABOLIC ADAPTATION AROUND PARTURITION}

Newborn calves depend on the timely supply of $\operatorname{Ig} G$ via colostrum in their first hours of life (Weaver et al., 2000; Conneely et al., 2014). Furthermore, precocial animals such as bovines require milk that is rapidly digestible and frequently available immediately after birth (Hayssen, 1993; Skibiel et al., 2013). Compared with other species, endocrine changes in dairy cows, in particular the decrease in progesterone and peaking concentrations of prolactin and glucocorticoids, occur before the end of term and enable the onset of copious milk production directly at parturition (Figure 2; Hoffmann et al., 1973; Gross et al., 2014a). Thus, milk is immediately available for the newborn calf. Furthermore, significant amounts of colostrum could already be obtained during the few hours before parturition (Gross et al., 2014a). Within a very narrow time frame in the periparturient period, quality and volume of mammary secretions could be replenished after milking once prepartum (Gross et al., 2014a; Baumrucker et al., 2016). This could ensure the neonatal supply of sufficient IgG in cases of dystocia and milk leakage before calving. However, with the second milk removal (suckling or machine milking), concentrations of IgG rapidly decline as the blood-milk barrier closes (Figure 2; Levieux and Ollier, 1999; Wall et al., 2015). Concomitantly, digestive tract activity on calves increases and intact maternal antibodies can no longer be transferred across the intestinal barrier (Stott et al., 1979; Weaver et al., 2000).

In dairy cows, colostrum yield is commonly severalfold higher than the actual calf requirements. Several reviews investigated cow- and calf-side factors, including the effect of seasonal variation, that are associated with colostrum yield and quality (Weaver et al., 2000; Morin et al., 2010). The relationship between colostrum yield and quality needs to be addressed. Although older studies tried to give thresholds for colostrum yield beyond that at which its quality might be considered poor (Pritchett et al., 1991), newer investigations could not identify any relationship between yield and IgG concentration in colostrum (Baumrucker et al., 2010; Gross et al., 2014a). In addition, the interval between calving and time of first milking does not negatively affect colostrum quality, at least up to $12 \mathrm{~h}$ after calving (Morin et al., 2010; Conneely et al., 2013; Gross et al., 2017). However, as stated above, the closure of the blood-milk barrier in cows and of the intestinal barrier in calves shortly after parturition necessitates a timely and sufficient supply of colostrum that is essential for neonatal 


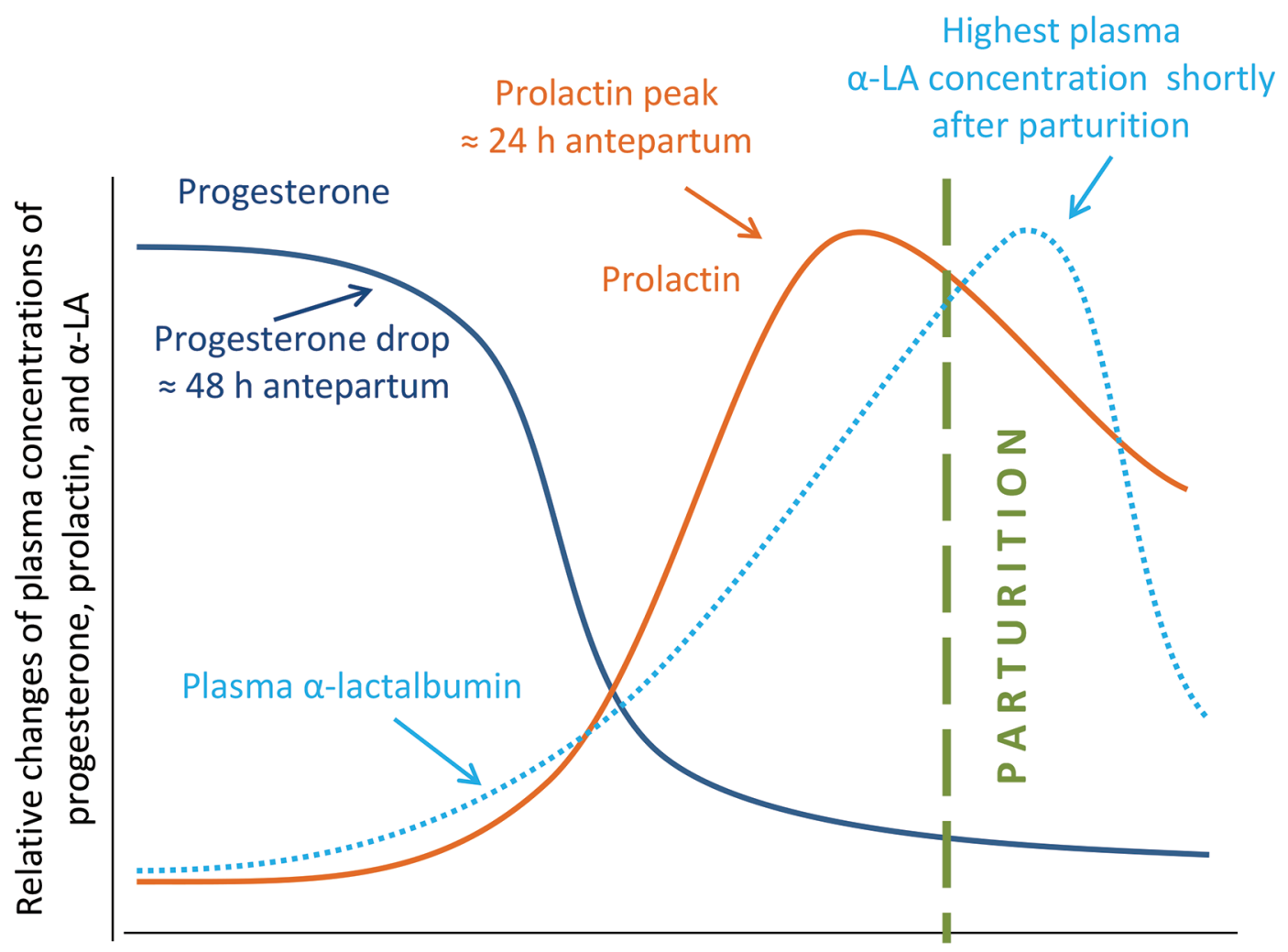

Time relative to parturition

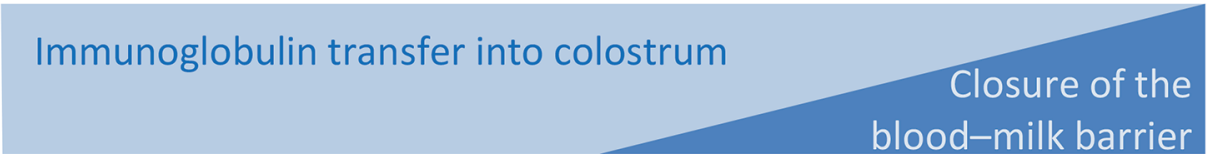

Figure 2. Periparturient pattern of plasma concentrations of prolactin, progesterone, and $\alpha$-LA in dairy cows. Prominent processes associated with endocrine changes are the transfer of maternal IgG into colostrum and the closure of the blood-milk barrier. The PGF ${ }_{2 \alpha}$-induced decrease in progesterone initiates the release of prolactin and the process of lactogenesis. Elevated prolactin concentrations before parturition trigger the closure of the blood-milk barrier and thus gradually terminate the further transfer of blood-derived proteins such as IgG. Graphs are adapted from Gross et al. (2014a) and Wall et al. (2015).

calf immunity because direct transfer over the maternal placenta is not possible in ungulate species (Langer, 2009; Baumrucker and Bruckmaier, 2014). Calves that could acquire a high status of passive immunization via colostrum were shown to suffer less from diarrhea and pneumonia and to have a greater BW gain, positively affecting their further development (Furman-Fratczak et al., 2011; Raboisson et al., 2016). Hence, careful colostrum and calf management are crucial for reducing the need for antimicrobial drug application.

Several approaches have been developed to assess colostrum quality using its physical properties. Color measurement did not result in an improved estimation of IgG compared with other on-farm devices (Argüello et al., 2005; Gross et al., 2014b) but might be an additional tool for automation in precision livestock farming equipment. Specific density is used by colostrometers or colostrum densimeters, whereas the refractive index is determined with optical Brix refractometers (Chigerwe et al., 2008; Quigley et al., 2013). Both technologies are easy to handle and provide an immediate estimate of colostral IgG content (Chigerwe et al., 2008; Bartier et al., 2015). However, fat and protein content as well as temperature affect measurements, and specificity and sensitivity are only moderate (Morin et al., 2001; Bartier et al., 2015; Gross et al., 2017). The closest relationship was shown with milk protein content indirectly representing the concomitant Ig content (Quigley et al., 2013; Bartier et al., 2015; Gross et al., 2017). Despite the limitations of these methods, the identification of superior colostrum quality in terms of gross composition supports the calves' supply with more nutrients and energy. On the other side, maternal energy expenditure for milk component synthesis (i.e., fat and pro- 
tein) is higher in superior colostrum. The relevance and limitations of energy availability for milk synthesis and the maintenance of other physiologic functions around parturition and early lactation were demonstrated in cows exposed to the milk fat depressing effect of CLA (Bauman et al., 2008; Harvatine and Bauman, 2011; Ma et al., 2015). When less energy is required for milk component synthesis, cows have less metabolic stress and abundant energy can be distributed to other competing tasks such as reproduction or the immune system (Gross et al., 2018a; Oliveira et al., 2018). Besides IgG, further bioactive components [e.g., vitamins, insulin, IGF-1, and serotonin (5-HT)] are highly concentrated in colostrum (Baumrucker and Blum, 1993; Blum and Hammon, 2000; Kessler et al., 2018). Cows already milked before calving had higher 5-HT concentrations in milk compared with cows milked for the first time shortly after parturition (Laporta et al., 2014). Higher 5 -HT concentrations in colostrum were represented by correspondingly elevated 5-HT concentrations in the serum of calves (Laporta et al., 2014).

Multiparous cows are known to show better colostrum quality compared with primiparous cows (Gulliksen et al., 2008; Gross et al., 2017). However, high variation in colostrum quality exists between and within farms (Baumrucker et al., 2010) as well as among individual quarters within a cow (Gross et al., 2016b, 2017; Samarütel et al., 2016). Many efforts were undertaken to study the mechanisms behind these observations. The blood-milk barrier enables the transfer of bioactive components into colostrum before the end of term. Different transport mechanisms were shown for the transfer of $\operatorname{IgG}_{1}$ and $\mathrm{IgG}_{2}$ into colostrum (Samarütel et al., 2016), which further explained the differential decline pattern of the respective factors in milk after parturition (Levieux and Ollier, 1999; Wall et al., 2015). Interestingly, the level of IgG in maternal circulation before calving did not affect the transfer rate into and the IgG concentration of colostrum (Baumrucker et al., 2016).

So far, only colostrum of cows with a preceding dry period was considered. But what happens to colostrum quality if one continues milking until calving? The process of colostrum formation, called colostrogenesis, is supposed to start a few weeks to a couple of days before calving (Barrington et al., 2001; Baumrucker and Bruckmaier, 2014). Occurrence of maternal antibodies in mammary secretions was detected $6 \mathrm{~d}$ before calving in continuously milked cows (Baumrucker et al., 2014). Cows without a dry period had lower colostrum volume at the first milking after calving and lower IgG concentration compared with cows undergoing a regular dry period of at least $42 \mathrm{~d}$ (Baumrucker et al., 2014; Verweij et al., 2014). Shortening the dry period, however, did not affect colostrum quality compared with a $0-d$ dry period (Annen et al., 2004; Watters et al., 2008). Although in regularly dried-off cows the colostral IgG transfer and content seems to be widely independent of prepartum progesterone and prolactin changes (Gross et al., 2014a), Baumrucker et al. (2014) observed a disrupted prolactin peak in continuously milked cows that might explain the lower colostrum quality when the dry period is omitted. Due to the high variation in colostrum quality between and within farms (Baumrucker et al., 2010; Morrill et al., 2012) as well as among individual quarters within a cow (Gross et al., 2016b, 2017; Samarütel et al., 2016), omitting the dry period does not necessarily cause poor calf health but does require more awareness in this regard. After the colostral period, milk composition and milk yield change gradually.

\section{ADAPTATION MECHANISMS ASSOCIATED WITH CHANGING METABOLIC REQUIREMENTS OF THE MAMMARY GLAND DURING THE COURSE OF LACTATION}

\section{Milk Yield and Metabolic Responses Related to Changing Energy Availability}

The transition from late gestation to lactation is considered the most striking and challenging period in the lactation cycle of dairy cows. The evolutionarily anchored maternal care behavior established lactation to provide a customized, complete food for the offspring over a long period (Langer, 2008; Oftedal, 2012). The constant availability and composition of milk widely independent of the dam's nutritional and health status ensure growth and survival of the neonate (Langer, 2008). The gradual development of the calf to a ruminant is indirectly reflected by the shape of the lactation curve: the sharp increase of milk production until peak lactation mirrors the growing and initially exclusive demand from the calf, whereas the declining phase of the lactation curve coincides with the decreasing importance of milk as the sole feed source (Hayssen, 1993; Langer, 2008). Corresponding with the lactation curve, metabolic priority and requirements of the mammary gland change distinctly, thereby draining nutrients from circulation toward milk synthesis with changing tenacity. Knowledge about physiological adaptation responses of the mammary gland to available nutrients at various stages of lactation is essential for making management decisions (e.g., selection for breeding, formulation of diets, time of insemination, and so on).

High milk production in the first days of lactation concomitantly implies elevated energy and nutrient requirements; however, the decline in periparturient DMI and the already low feed intake level do not 
cover the needs (Grummer et al., 2004; Douglas et al., 2006; Gross et al., 2011a). Due to the selection toward greater lactation performance, particularly during the early lactation period, initial milk yields above 30 or $40 \mathrm{~kg} / \mathrm{d}$ in the first days of lactation are common and not exceptional. Thus, the prevailing NEB triggering lipolysis already exposes high-producing cows to metabolic stress at the time of calving (Bell, 1995; LeBlanc, 2010). Consequently, predisposition to metabolic and infectious diseases is initiated at the very beginning of lactation. Additional factors such as inadequate feeding and overconditioning during the dry period may further aggravate metabolic adaptation and favor hypocalcemia, endometritis, and so on (Douglas et al., 2006; Roche et al., 2009). Colostrum yield varies considerably in dairy cows (Kessler et al., 2014a; Gross et al., 2016b): the amount of first milk may sometimes not even be sufficient for calves $(<2 \mathrm{~kg})$ but can range up to more than $20 \mathrm{~kg}$ (Kessler et al., 2014a). Similarly, milk production in the first days after calving shows a broad variation among cows. However, colostrum yield is not related to subsequent milk production and overall lactational performance (Kessler et al., 2014a). In addition, lower milk production shortly after parturition was associated with a lower metabolic load (Kessler et al., 2018).

Despite NEB, dairy cows even increase milk production during early lactation, whereas a similar energy deficiency at a later lactational stage was immediately followed by a reduction in milk yield to partly compensate for the lack of energy and nutrients (Figure 1; Gross et al., 2011a). Animal nutrition and physiology traditionally formulated diets that cover animal demands; currently, both disciplines increasingly aim at maintaining good animal health and product quality at a high performance level, thereby accepting a temporal nutrient and energy deficiency to a certain degree as long as the effect on performance is reversible.

Biological variation in adaptation responses to NEB in early lactation at similar performance levels between farms and even within a farm is notable (Kessel et al., 2008; Gross and Bruckmaier, 2015). Remarkably, the relative extent of metabolic responses to the lactationinduced NEB after parturition is repeatable in mid lactation (Figure 1; Gross and Bruckmaier, 2015), thus indicating at least partially a genetic background (Rocco and McNamara, 2013). Indeed, differences in the phenotypic expression of key metabolites during NEB in early lactation (plasma concentrations of glucose, NEFA, and BHB) are associated with respective differences in numerous genes and various pathways being responsible for metabolic adaptation (Ha et al., 2015). However, it must be emphasized that an elevated metabolic load does not automatically equate with poor animal health status. Early-lactating dairy cows with considerable variation in their metabolic status were followed in terms of their lifetime performance until culling (Gross et al., 2016a). The retrospective classification of cows assigned to either high or low metabolic load in early lactation was not related to the lifetime milk production finally achieved (Gross et al., 2016a).

\section{Endocrine Adaptations Related to Energy and Nutrient Homeostastis}

The somatotropic axis spanning the effects of growth hormone (GH), IGF-1, IGF binding proteins (IGFBP), and receptors for GH and IGF plays a crucial role in partitioning of nutrients toward the mammary gland. Despite reduced insulin sensitivity of peripheral tissues during early lactation supporting nutrient delivery for milk synthesis (Gross et al., 2011b; Bruckmaier and Gross, 2017), particularly IGFBP mediate distribution and effects of IGF-1 during catabolic stages (Kessler et al., 2013). In early lactation as well as later during a feed restriction period, hepatic gene expression of IGFBP-2 was upregulated, whereas mRNA abundance of IGFBP-3 was lower in early lactation and higher in mid lactation (Gross et al., 2011b). A clear relationship between plasma IGF-1 concentration, mRNA abundance, and protein levels of the associated IGFBP was identified independent of the stage of lactation (Kessler et al., 2013). The GH-IGF axis is, however, not rigidly set; circulating IGF-1 concentrations closely reflect current nutrient availability and are further decreased (compared with animals with a more moderate energy deficiency) when energy and nutrient deficiencies are aggravated (Zbinden et al., 2017). Similarly directed responses of IGF-1 were observed during catabolic stages in mid lactation, although to a lesser extent than in early lactation (Gross et al., 2011b; Kessler et al., 2013). These findings emphasize the pivotal role of IGF-1 in controlling nutrient partitioning along with the altered metabolic priority of the mammary gland throughout lactation. In this respect, differences in lactational performance of genetically divergent cow strains of the same breed could be explained by different IGF-1 and GH levels (Lucy et al., 2009; Grala et al., 2011). As IGF-1 concentrations were associated with the current metabolic load (Kessel et al., 2008; Zbinden et al., 2017) and similar adaptation responses repeatedly occurred at different lactational stages, IGF-1 was recently discussed as a marker for resilience and metabolic robustness in dairy cows (Gross and Bruckmaier, 2015; Bruckmaier and Gross, 2017; Ha et al., 2017b).

The characteristic transient loss of feedback of low IGF-1 concentrations associated with concomitantly el- 
evated GH levels (uncoupling of the somatotropic axis) triggers lipolysis of body fat tissues (Lucy et al., 2001; Renaville et al., 2002). Simultaneously, low insulin secretion and low insulin sensitivity of peripheral tissues except for the mammary gland inhibit the reuptake of circulating nutrients and additionally support lipolysis (De Koster and Opsomer, 2013). Adipocytokines interact along with insulin in nutrient uptake to peripheral tissues (De Koster et al., 2017). Low circulating adiponectin concentrations in mice were associated with a higher degree of insulin resistance, whereas an increase in adiponectin enhanced insulin sensitivity (Fang and Judd, 2018). In dairy cows, concentrations of adiponectin are lowest shortly after parturition (Giesy et al., 2012; Singh et al., 2014), which supposes adiponectin to contribute to the development of insulin resistance along with potential stimulating effects on hepatic gluconeogenesis (Zhou et al., 2005; Fang and Judd, 2018). With decreasing insulin sensitivity, the decreasing adiponectin and leptin concentrations observed in early lactation consequently further support direction of glucose to the mammary gland (Gross et al., 2011b; Singh et al., 2014), whereas peripheral tissues do not significantly absorb glucose at this time. Concomitantly, at a later induced NEB in mid lactation, insulin, leptin, and adiponectin responded only marginally, indicating a lower metabolic priority of the mammary gland (Gross et al., 2011b; Singh et al., 2014).

The fate of circulating glucose is predominantly determined by the cow's physiological status in terms of health and performance level. The immune system claims glucose just as the central nervous system, the kidney, and of course the mammary gland to operate the synthesis of lactose and other milk constituents. Glucose requirements for lactation account for up to approximately $85 \%$ of the turnover, wheras gluconeogenesis is concomitantly starting at a low rate immediately after parturition (Aschenbach et al., 2010). Most of the glucose is taken up into the mammary gland via insulin independent glucose transporter (GLUT) 1 (Zhao and Keating, 2007a,b). At later lactational stages, the importance of insulin-dependent glucose intake by, for example, GLUT4 increases (Mattmiller et al., 2011; Gross et al., 2015b), and the mammary gland is less dominant in draining glucose during an established nutrient homeostasis. The question of whether glucose in early lactation is limiting for milk synthesis was addressed by different approaches. Infusing glucose in early lactation temporarily increased milk yield (Brown and Allen, 2013; Grossen-Rösti et al., 2018), although some authors argued that import capacities via GLUT and sodium-dependent glucose transporters into the mammary gland are limited (Zhao and Keat- ing, 2007b). In mid- to late-lactating cows, we could show that the expression of glucose transporters in the mammary gland seems to not be affected by a shortage of glucose forced by insulin infusion, whereas enzymes and milk components directly depending on glucose as precursor were immediately downregulated (Gross et al., 2015b). Conversely, during a hyperinsulinemic euglycemic condition in which glucose availability was not limited, glucose transporters were even downregulated (Gross et al., 2015b). During LPS-induced mastitis in combination with hypoglycemia, mammary gland metabolism was more aligned to save glucose for the immune system compared with the situation in which glucose availability was not limited (Vernay et al., 2012). Glucose infusions in transition dairy cows before and after calving revealed differences in the endocrine response (Sartin et al., 1985; Grossen-Rösti et al., 2018). Glucose clearance rate was higher in early lactation than in late gestation accompanied by a shortterm increase of milk production on the infusion day (Grossen-Rösti et al., 2018). However, administered glucose was not fully converted into additional milk synthesis. Increases in plasma insulin levels indicated a transient overcoming of insulin resistance or at least an increase in insulin sensitivity of peripheral tissues such as adipose tissue during hyperglycemic conditions (Grossen-Rösti et al., 2018). An absolute insulin resistance is consequently not given, but prevailing glucose concentrations in early lactation are by far too low to induce reuptake for storage purposes. In adipose tissue, Jaakson et al. (2018) found higher amounts of the insulin-dependent GLUT4 before parturition than in early lactation, whereas insulin receptors were upregulated postpartum. The increased clearance of glucose and reduced insulin response in early lactation compared with late gestation indicated an immediate usage of glucose for metabolic purposes (Grossen-Rösti et al., 2018; Jaakson et al., 2018). Overconditioning of dairy cows during the dry period resulted in the development of insulin resistance of adipose tissue before calving, less GLUT4 protein synthesis, and intensified adipose tissue lipolysis after calving (Jaakson et al., 2018). Regarding glucose metabolism, body condition did not affect adipose tissue insulin resistance postpartum (Jaakson et al., 2018). When glucose availability due to infusion in early lactation was not limited, NEFA and BHB concentrations decreased immediately, indicating less lipolysis and reuptake of peripheral tissues (Grossen-Rösti et al., 2018). Saving the partly essential glucose during periods of high demand seems likely a strategy of dairy cows to maintain metabolic priority of the mammary gland in early lactation. In this respect, feeding CLA was shown to spare glucose during early 
lactation (Hötger et al., 2013; Grossen-Rösti et al., 2018) and during an immune challenge (Gross et al., 2018a).

\section{Adaptation Responses of the Lipid and Ketone Body Metabolism}

Elevated plasma BHB concentrations are attributed to the high mobilization of body fat store-derived fatty acids, which exceed the oxidative capacity of the liver (Bell, 1995; Drackley et al., 2006). Cows face a dilemma of the competition for oxaloacetate either depleted for gluconeogenesis or required to maintain the citric acid cycle for oxidation of fatty acids (Aschenbach et al., 2010). Consequently, fatty acids that are not oxidized are converted to ketone bodies or re-esterified to triglycerides within the liver (Grummer, 1993; Bobe et al., 2004). This adaptation may happen within a very narrow time. We could show a mild to severe fatty liver already within the first week after calving, although NEFA concentrations and metabolic load reached highest values a few weeks later (Gross et al., 2013). The concomitant low cholesterol concentrations in early lactation likely limit the hepatic triglyceride export despite an upregulation of hepatic cholesterol biosynthesis (Kessler et al., 2014b). Ha et al. (2017a) recently showed with a liver transcriptome analysis that pathways associated with cholesterol are essentially involved in adaptation processes of metabolism during the transition period. Forcing NEB with adipose tissue mobilization at a later lactational stage, however, did not result in a considerable lipid accumulation in the liver as cholesterol concentrations were elevated, supporting hepatic triglyceride export (Gross et al., 2013, 2015a). Supplementing dairy cow diets with CLA resulted in higher plasma cholesterol and triglyceride concentrations in early lactation, indicating similar beneficial effects on hepatic lipid export and improved efficiency of circulating nutrients (Galamb et al., 2017; Grossen-Rösti et al., 2018).

Ketone bodies such as acetone, acetoacetate, and BHB are known to depress feed intake (Laeger et al., 2010), reduce fertility (Ospina et al., 2010; Raboisson et al., 2014), and impair immune function (Suriyasathaporn et al., 1999). Thus, excessive release of fatty acids from the adipose tissue and consequent formation of ketone bodies are detrimental when immune competence is low and cows in early lactation are highly susceptible to metabolic and infectious diseases anyway (Sordillo et al., 2009; Trevisi et al., 2012; Bradford et al., 2015). Despite their adverse effects, ketone bodies may be considered an energy source for certain tissues and cells (e.g., skeletal muscle, heart, and brain; Ruderman and Goodman, 1973; Laffel, 1999). Recently,
Zarrin et al. (2014a) and Gross et al. (2018a) showed that BHB is preferentially used before glucose by the immune system during inflammation. This might further support the ability of dairy cows to spare glucose. On the other hand, elevated BHB concentrations were shown to depress gluconeogenesis and thus plasma glucose concentrations independent of lactational stage (Zarrin et al., 2014b, 2017). As mentioned above, low insulin concentrations and the high glucose requirements in early lactation trigger mobilization of body reserves. Excessively mobilized fatty acids that are not oxidized consequently favor the formation of ketone bodies, which again inhibit gluconeogenesis. The apparently abundant energy in circulation of early-lactating dairy cows as signaled by elevated ketone bodies paradoxically results in a concomitantly reduced feed intake (Laeger et al., 2010; Rojas-Morales et al., 2016). The increased specific needs of glucose for milk production were not foreseen in evolution. The majority of dairy cows today face a temporary exposure to hyperketonemia and associated health disorders (Ospina et al., 2010; McArt et al., 2012). Plasma BHB concentrations above 1.2 to $1.4 \mathrm{mmol} / \mathrm{L}$ might already indicate subclinical ketosis (LeBlanc, 2010; Suthar et al., 2013). Moreover, the risk of accompanying metabolic and infectious health disorders increases disproportionally when ketone bodies are elevated (Ospina et al., 2010; McArt et al., 2012). However, biological variation in metabolic load of dairy cows is notable (Kessel et al., 2008; Gross and Bruckmaier, 2015). Again, variation in plasticity of metabolic adaptation responses toward different challenges, in particular the establishment and maintenance of lactation without impairing animal health and performance, provides an open potential for future breeding and selection of dairy cows.

\section{CONCLUSIONS AND OUTLOOK}

The question of whether breeding aggravated metabolic priority of the lactating mammary gland to achieve today's performance level in dairy cows cannot be answered completely. The evolutionarily conserved direction of nutrients to the mammary gland immediately after calving certainly provided the basis for successful selection toward higher milk yields. Endocrine and metabolic adaptations differ distinctly among developing, remodeling, and lactational stages of the mammary gland. Any changes in management practices create new challenges. Early metabolic programming and rearing strategies of calves determine the later lactational performance of cows. Additionally, failures in adult cow management between successive calvings affect metabolic adaptation mechanisms in the following lactation period. Although high milk produc- 
tion imposes challenges on animal health, feeding, and management, the considerable variation in adaptation mechanisms creates perspectives for more efficient and sustainable dairy farming. Metabolic plasticity describes the adaptation capacity of the whole organism, particularly the mammary gland, depending on available energy and nutrients. Approaches toward more sustainable dairy production must take the different functional stages and the associated adaptation mechanisms of the mammary gland into account. Individual variation in metabolic plasticity in early-lactating dairy cows might be a target for future dairy cow breeding.

\section{REFERENCES}

Akers, R. M. 2000. Selection for milk production from a lactation biology viewpoint. J. Dairy Sci. 83:1151-1158. https://doi.org/10 .3168/jds.S0022-0302(00)74981-2.

Akers, R. M. 2017a. Triennial Lactation Symposium/BOLFA: Plasticity of mammary development in the prepubertal bovine mammary gland. J. Anim. Sci. 95:5653-5663. https://doi.org/10.2527/ jas2017.1792.

Akers, R. M. 2017b. A 100-year review: Mammary development and lactation. J. Dairy Sci. 100:10332-10352. https://doi.org/10.3168/ jds.2017-12983.

Annen, E. L., R. J. Collier, M. A. McGuire, J. L. Vicini, J. M. Ballam, and M. J. Lormore. 2004. Effect of modified dry period lengths and bovine somatotropin on yield and composition of milk from dairy cows. J. Dairy Sci. 87:3746-3761. https://doi.org/10.3168/ jds.S0022-0302(04)73513-4.

Argüello, A., N. Castro, and J. Capote. 2005. Short communication: Evaluation of a color method for testing immunoglobulin G concentration in goat colostrum. J. Dairy Sci. 88:1752-1754. https:// doi.org/10.3168/jds.S0022-0302(05)72849-6.

Aschenbach, J. R., N. B. Kristensen, S. S. Donkin, H. M. Hammon, and G. B. Penner. 2010. Gluconeogenesis in dairy cows: The secret of making sweet milk from sour dough. IUBMB Life 62:869-877. https://doi.org/10.1002/iub.400.

Barkema, H. W., M. A. G. von Keyserlingk, J. P. Kastelic, T. J. G. M. Lam, C. Luby, J. P. Roy, S. J. LeBlanc, G. P. Keefe, and D. F. Kelton. 2015. Invited review: Changes in the dairy industry affecting dairy cattle health and welfare. J. Dairy Sci. 98:7426-7445. https://doi.org/10.3168/jds.2015-9377.

Barrington, G. M., T. B. McFadden, M. T. Huyler, and T. E. Besser. 2001. Regulation of colostrogenesis in cattle. Livest. Prod. Sci. 70:95-104. https://doi.org/10.1016/S0301-6226(01)00201-9.

Bartier, A. L., M. C. Windeyer, and L. Doepel. 2015. Evaluation of on-farm tools for colostrum quality measurement. J. Dairy Sci. 98:1878-1884. https://doi.org/10.3168/jds.2014-8415.

Bauman, D. E., and W. B. Currie. 1980. Partitioning of nutrients during pregnancy and lactation: A review of mechanisms involving homeostasis and homeorhesis. J. Dairy Sci. 63:1514-1529.

Bauman, D. E., J. W. Perfield 2nd, K. J. Harvatine, and L. H. Baumgard. 2008. Regulation of fat synthesis by conjugated linoleic acid: Lactation and the ruminant model. J. Nutr. 138:403-409.

Baumrucker, C. R., and J. R. Blum. 1993. Secretion of insulin-like growth factors in milk and their effect on the neonate. Livest. Prod. Sci. 35:49-72. https://doi.org/10.1016/0301-6226(93)90181 $-\mathrm{G}$.

Baumrucker, C. R., and R. M. Bruckmaier. 2014. Colostrogenesis: IgG1 transcytosis mechanisms. J. Mammary Gland Biol. Neoplasia 19:103-117. https://doi.org/10.1007/s10911-013-9313-5.

Baumrucker, C. R., A. M. Burkett, A. L. Magliaro-Macrina, and C. D. Dechow. 2010. Colostrogenesis: Mass transfer of immunoglobulin G1 into colostrum. J. Dairy Sci. 93:3031-3038. https://doi.org/10 $.3168 /$ jds.2009-2963.
Baumrucker, C. R., C. D. Dechow, A. L. Macrina, J. J. Gross, and R. M. Bruckmaier. 2016. Mammary immunoglobulin transfer rates following prepartum milking. J. Dairy Sci. 99:9254-9262. https:// doi.org/10.3168/jds.2016-11370.

Baumrucker, C. R., R. S. Zbinden, H. A. van Dorland, G. J. Remmelink, B. Kemp, A. T. van Knegsel, and R. M. Bruckmaier. 2014 Continuous milking of dairy cows disrupts timing of peak IgG concentration appearance in mammary secretions. J. Dairy Res. 81:403-409. https://doi.org/10.1017/S002202991400034X.

Beerda, B., J. E. Kornalijnslijper, J. T. van der Werf, E. N. Noordhuizen-Stassen, and H. Hopster. 2004. Effects of milk production capacity and metabolic status on HPA function in early postpartum dairy cows. J. Dairy Sci. 87:2094-2102. https://doi.org/10.3168/ jds.S0022-0302(04)70027-2.

Beever, D. E. 2006. The impact of controlled nutrition during the dry period on dairy cow health, fertility and performance. Anim. Reprod. Sci. 96:212-226. https://doi.org/10.1016/j.anireprosci.2006 .08 .002 .

Bell, A. W. 1995. Regulation of organic nutrient metabolism during transition from late pregnancy to early lactation. J. Anim. Sci. 73:2804-2819.

Berry, D. P. 2018. Symposium review: Breeding a better cow-Will she be adaptable? J. Dairy Sci. 101:3665-3685. https://doi.org/10 $.3168 /$ jds.2017-13309.

Blum, J. W., and H. Hammon. 2000. Colostrum effects on the gastrointestinal tract, and on nutritional, endocrine and metabolic parameters in neonatal calves. Livest. Prod. Sci. 66:151-159. https: //doi.org/10.1016/S0301-6226(00)00222-0.

Bobe, G., J. W. Young, and D. C. Beitz. 2004. Invited review: Pathology, etiology, prevention and treatment of fatty liver in dairy cows. J. Dairy Sci. 87:3105-3124. https://doi.org/10.3168/jds.S0022 -0302(04)73446-3.

Boogaard, B. K., B. B. Bock, S. J. Oosting, J. S. C. Wiskerke, and A. J. van der Zijpp. 2011a. Social acceptance of dairy farming: The ambivalence between the two faces of modernity. J. Agric. Environ. Ethics 24:259-282. https://doi.org/10.1007/s10806-010 -9256-4.

Boogaard, B. K., S. J. Oosting, B. B. Bock, and J. S. Wiskerke. 2011b. The sociocultural sustainability of livestock farming: An inquiry into social perceptions of dairy farming. Animal 5:1458-1466. https://doi.org/10.1017/S1751731111000371.

Bradford, B. J., K. Yuan, J. K. Farney, L. K. Mamedova, and A. J. Carpenter. 2015. Invited review: Inflammation during the transition to lactation: New adventures with an old flame. J. Dairy Sci. 98:6631-6650. https://doi.org/10.3168/jds.2015-9683.

Brown, W. E., and M. S. Allen. 2013. Effects of intrajugular glucose infusion on feed intake, milk yield, and metabolic responses of early postpartum cows fed diets varying in protein and starch concentration. J. Dairy Sci. 96:7132-7142. https://doi.org/10.3168/ jds.2013-6636.

Bruckmaier, R. M., and J. J. Gross. 2017. Lactational challenges in transition dairy cows. Anim. Prod. Sci. 57:1471-1481. https://doi .org/10.1071/AN16657.

Capper, J. L., R. A. Cady, and D. E. Bauman. 2009. The environmental impact of dairy production: 1944 compared with 2007. J. Anim. Sci. 87:2160-2167. https://doi.org/10.2527/jas.2009-1781.

Capuco, A. V., and R. M. Akers. 1999. Mammary involution in dairy animals. J. Mammary Gland Biol. Neoplasia 4:137-144.

Capuco, A. V., R. M. Akers, and J. J. Smith. 1997. Mammary growth in Holstein cows during the dry period: Quantification of nucleic acids and histology. J. Dairy Sci. 80:477-487. https://doi.org/10 .3168/jds.S0022-0302(97)75960-5.

Cardoso, C. S., M. J. Hötzel, D. M. Weary, J. A. Robbins, and M. A. G. von Keyserlingk. 2016. Imagining the ideal dairy farm. J. Dairy Sci. 99:1663-1671. https://doi.org/10.3168/jds.2015-9925.

Chen, J., J. J. Gross, H. A. van Dorland, G. J. Remmelink, R. M. Bruckmaier, B. Kemp, and A. T. van Knegsel. 2015. Effects of dry period length and dietary energy source on metabolic status and hepatic gene expression of dairy cows in early lactation. J. Dairy Sci. 98:1033-1045. https://doi.org/10.3168/jds.2014-8612. 
Chen, J., A. Kok, G. J. Remmelink, J. J. Gross, R. M. Bruckmaier, B. Kemp, and A. T. van Knegsel. 2016a. Effects of dry period length and dietary energy source on lactation curve characteristics over 2 subsequent lactations. J. Dairy Sci. 99:9287-9299. https://doi.org/ $10.3168 / j d s .2016-11253$.

Chen, J., G. J. Remmelink, J. J. Gross, R. M. Bruckmaier, B. Kemp, and A. T. M. van Knegsel. 2016b. Effects of dry period length and dietary energy source on milk yield, energy balance, and metabolic status of dairy cows over 2 consecutive years: Effects in the second year. J. Dairy Sci. 99:4826-4838. https://doi.org/10.3168/jds.2015 -10742 .

Chigerwe, M., J. W. Tyler, J. R. Middleton, J. N. Spain, J. S. Dill, and B. J. Steevens. 2008. Comparison of four methods to assess colostral IgG concentration in dairy cows. J. Am. Vet. Med. Assoc. 233:761-766. https://doi.org/10.2460/javma.233.5.761.

Collier, R. J., E. L. Annen-Dawson, and A. Pezeshki. 2012. Effects of continuous lactation and short dry periods on mammary function and animal health. Animal 6:403-414. https://doi.org/10.1017/ S1751731111002461.

Conneely, M., D. P. Berry, J. P. Murphy, I. Lorenz, M. L. Doherty, and E. Kennedy. 2014. Effect of feeding colostrum at different volumes and subsequent number of transition milk feeds on the serum immunoglobulin $\mathrm{G}$ concentration and health status of dairy calves. J. Dairy Sci. 97:6991-7000. https://doi.org/10.3168/jds.2013-7494.

Conneely, M., D. P. Berry, R. Sayers, J. P. Murphy, I. Lorenz, M. L. Doherty, and E. Kennedy. 2013. Factors associated with the concentration of immunoglobulin $\mathrm{G}$ in the colostrum of dairy cows. Animal 7:1824-1832. https://doi.org/10.1017/S1751731113001444.

Dann, H. M., N. B. Litherland, J. P. Underwood, M. Bionaz, A. D'Angelo, J. W. McFadden, and J. K. Drackley. 2006. Diets during far-off and close-up dry periods affect periparturient metabolism and lactation in multiparous cows. J. Dairy Sci. 89:3563-3577. https://doi.org/10.3168/jds.S0022-0302(06)72396-7.

Davis, S. R. 2017. Triennial Lactation Symposium/BOLFA: Mammary growth during pregnancy and lactation and its relationship with milk yield. J. Anim. Sci. 95:5675-5688. https://doi.org/10 $.2527 / \mathrm{jas} 2017.1733$.

Davis Rincker, L. E., M. J. Vandehaar, C. A. Wolf, J. S. Liesman, L. T. Chapin, and M. S. Weber Nielsen. 2011. Effect of intensified feeding of heifer calves on growth, pubertal age, calving age, milk yield, and economics. J. Dairy Sci. 94:3554-3567. https://doi.org/ 10.3168/jds.2010-3923.

De Koster, J., C. Urh, M. Hostens, W. Van den Broeck, H. Sauerwein, and G. Opsomer. 2017. Relationship between serum adiponectin concentration, body condition score, and peripheral tissue insulin response of dairy cows during the dry period. Domest. Anim. Endocrinol. 59:100-104. https://doi.org/10.1016/j.domaniend.2016 .12 .004 .

De Koster, J. D., and G. Opsomer. 2013. Insulin resistance in dairy cows. Vet. Clin. North Am. Food Anim. Pract. 29:299-322. https: //doi.org/10.1016/j.cvfa.2013.04.002.

Douglas, G. N., T. R. Overton, H. G. Bateman, H. M. Dann, and J. K. Drackley. 2006. Prepartal plane of nutrition, regardless of dietary energy source, affects periparturient metabolism and dry matter intake in Holstein cows. J. Dairy Sci. 89:2141-2157. https://doi .org/10.3168/jds.S0022-0302(06)72285-8.

Drackley, J. K. 1999. ADSA Foundation Scholar Award. Biology of dairy cows during the transition period: The final frontier? J. Dairy Sci. 82:2259-2273.

Drackley, J. K., S. S. Donkin, and C. K. Reynolds. 2006. Major advances in fundamental dairy cattle nutrition. J. Dairy Sci. 89:13241336. https://doi.org/10.3168/jds.S0022-0302(06)72200-7.

Drackley, J. K., M. Heather, G. Dann, N. Douglas, N. A. Janovick Guretzky, N. B. Litherland, J. P. Underwood, and J. J. Loor. 2005. Physiological and pathological adaptations in dairy cows that may increase susceptibility to periparturient diseases and disorders. Ital. J. Anim. Sci. 4:323-344. https://doi.org/10.4081/ijas .2005 .323 .

Eastridge, M. L. 2006. Major advances in applied dairy cattle nutrition. J. Dairy Sci. 89:1311-1323. https://doi.org/10.3168/jds .S0022-0302(06)72199-3.
Fang, H., and R. L. Judd. 2018. Adiponectin regulation and function. Compr. Physiol. 8:1031-1063. https://doi.org/10.1002/cphy .c170046.

Fleischer, P., M. Metzner, M. Beyerbach, M. Hoedemaker, and W. Klee. 2001. The relationship between milk yield and the incidence of some diseases in dairy cows. J. Dairy Sci. 84:2025-2035. https:/ /doi.org/10.3168/jds.S0022-0302(01)74646-2.

Frey, H. J., J. J. Gross, R. Petermann, S. Probst, R. M. Bruckmaier, and P. Hofstetter. 2018. Performance, body fat reserves and plasma metabolites in Brown Swiss dairy cows: Indoor feeding versus pasture-based feeding. J. Anim. Physiol. Anim. Nutr. (Berl.) 102:e746-e757. https://doi.org/10.1111/jpn.12829.

Furman-Fratczak, K., A. Rzasa, and T. Stefaniak. 2011. The influence of colostral immunoglobulin concentration in heifer calves' serum on their health and growth. J. Dairy Sci. 94:5536-5543. https:// doi.org/10.3168/jds.2010-3253.

Gabai, G. 2003. Physiological and metabolic adaptations in the mammary gland and consequences for the dairy cow. Vet. Res. Commun. 27(Suppl. 1):129-136.

Galamb, E., V. Faigl, M. Keresztes, Z. Csillik, A. Tröscher, P. Elek, M. Kulcsár, G. Huszenicza, H. Fébel, and F. Husvéth. 2017. Effect of pre- and post-partum supplementation with lipid-encapsulated conjugated linoleic acid on milk yield and metabolic status in multiparous high-producing dairy cows. J. Anim. Physiol. Anim. Nutr. (Berl.) 101:1026-1035. https://doi.org/10.1111/jpn.12544.

Geiger, A. J., C. L. M. Parsons, and R. M. Akers. 2016. Feeding a higher plane of nutrition and providing exogenous estrogen increases mammary gland development in Holstein heifer calves. J. Dairy Sci. 99:7642-7653. https://doi.org/10.3168/jds.2016-11283.

Gerloff, B. J. 2000. Dry cow management for the prevention of ketosis and fatty liver in dairy cows. Vet. Clin. North Am. Food Anim. Pract. 16:283-292.

Giesy, S. L., B. Yoon, W. B. Currie, J. W. Kim, and Y. R. Boisclair. 2012. Adiponectin deficit during the precarious glucose economy of early lactation in dairy cows. Endocrinology 153:5834-5844. https: //doi.org/10.1210/en.2012-1765.

Grala, T. M., M. C. Lucy, C. V. C. Phyn, A. J. Sheahan, J. M. Lee, and J. R. Roche. 2011. Somatotropic axis and concentrate supplementation in grazing dairy cows of genetically diverse origin. J. Dairy Sci. 94:303-315. https://doi.org/10.3168/jds.2010-3773.

Gross, J., H. A. van Dorland, R. M. Bruckmaier, and F. J. Schwarz. 2011a. Performance and metabolic profile of dairy cows during a lactational and deliberately induced negative energy balance by feed restriction with subsequent realimentation. J. Dairy Sci. 94:1820-1830. https://doi.org/10.3168/jds.2010-3707.

Gross, J., H. A. van Dorland, F. J. Schwarz, and R. M. Bruckmaier. 2011b. Endocrine changes and liver mRNA abundance of somatotropic axis and insulin system constituents during negative energy balance at different stages of lactation in dairy cows. J. Dairy Sci. 94:3484-3494. https://doi.org/10.3168/jds.2011-4251.

Gross, J. J., and R. M. Bruckmaier. 2015. Repeatability of metabolic responses to a nutrient deficiency in early and mid-lactation and implications for robustness of dairy cows. J. Dairy Sci. 98:86348643. https://doi.org/10.3168/jds.2014-9246.

Gross, J. J., L. Grossen-Rösti, R. Héritier, A. Tröscher, and R. M. Bruckmaier. 2018a. Inflammatory and metabolic responses to an intramammary lipopolysaccharide challenge in early lactating cows supplemented with conjugated linoleic acid. J. Anim. Physiol. Anim. Nutr. (Berl.) 102:e838-e848. https://doi.org/10.1111/ jpn.12843.

Gross, J. J., L. Grossen-Rösti, F. Schmitz-Hsu, and R. M. Bruckmaier. 2016a. Metabolic adaptation recorded during one lactation does not allow predicting longevity in dairy cows. Schweiz. Arch. Tierheilkd. 158:565-571. https://doi.org/10.17236/sat00078.

Gross, J. J., E. C. Kessler, C. Albrecht, and R. M. Bruckmaier. 2015a. Response of the cholesterol metabolism to a negative energy balance in dairy cows depends on the lactational stage. PLoS One 10:e0121956. https://doi.org/10.1371/journal.pone.0121956.

Gross, J. J., E. C. Kessler, V. Bjerre-Harpoth, C. Dechow, C. R. Baumrucker, and R. M. Bruckmaier. 2014a. Peripartal progesterone and prolactin have little effect on the rapid transport of immuno- 
globulin G into colostrum of dairy cows. J. Dairy Sci. 97:29232931. https://doi.org/10.3168/jds.2013-7795.

Gross, J. J., E. C. Kessler, and R. M. Bruckmaier. 2014b. Colour measurement of colostrum for estimation of colostral IgG and colostrum composition in dairy cows. J. Dairy Res. 81:440-444. https:/ /doi.org/10.1017/S0022029914000466.

Gross, J. J., E. C. Kessler, and R. M. Bruckmaier. 2017. Quarter vs. composite colostrum composition assessed by Brix refractometry specific gravity and visual color appearance in primiparous and multiparous dairy cows. Transl. Anim. Sci. 1:26-35. https://doi .org $/ 10.2527 / \operatorname{tas} 2016.0001$.

Gross, J. J., G. Schüpbach-Regula, and R. M. Bruckmaier. 2016b. Rapid communication: Colostrum immunoglobulin concentration in mammary quarters is repeatable in consecutive lactations of dairy cows. J. Anim. Sci. 94:1755-1760. https://doi.org/10.2527/ jas.2016-0362.

Gross, J. J., F. J. Schwarz, K. Eder, H. A. van Dorland, and R. M. Bruckmaier. 2013. Liver fat content and lipid metabolism in dairy cows during early lactation and during a mid-lactation feed restriction. J. Dairy Sci. 96:5008-5017. https://doi.org/10.3168/jds .2012-6245

Gross, J. J., H. A. van Dorland, O. Wellnitz, and R. M. Bruckmaier. 2015b. Glucose transport and milk secretion during manipulated plasma insulin and glucose concentrations and during LPSinduced mastitis in dairy cows. J. Anim. Physiol. Anim. Nutr. (Berl.) 99:747-756. https://doi.org/10.1111/jpn.12259.

Gross, J. J., R. S. Zbinden, F. Dohme-Meier, and R. M. Bruckmaier. 2018b. Adrenal cortex reactivity in dairy cows differs between lactational stages and between different feeding levels. J. Anim. Physiol. Anim. Nutr. (Berl.) 102:e309-e315. https://doi.org/10 $.1111 /$ jpn.12746.

Grossen-Rösti, L., E. C. Kessler, A. Tröscher, R. M. Bruckmaier, and J. J. Gross. 2018. Hyperglycaemia in transition dairy cows: Effects of lactational stage and conjugated linoleic acid supplementation on glucose metabolism and turnover. J. Anim. Physiol. Anim. Nutr. (Berl.) 102:483-494. https://doi.org/10.1111/jpn.12771.

Grummer, R., and R. Rastani. 2004. Why reevaluate dry period length? J. Dairy Sci. 87:E77-E85. https://doi.org/10.3168/jds .S0022-0302(04)70063-6.

Grummer, R. R. 1993. Etiology of lipid-related metabolic disorders in periparturient dairy cows. J. Dairy Sci. 76:3882-3896. https://doi .org/10.3168/jds.S0022-0302(93)77729-2.

Grummer, R. R., D. G. Mashek, and A. Hayirli. 2004. Dry matter intake and energy balance in the transition period. Vet. Clin. North Am. Food Anim. Pract. 20:447-470. https://doi.org/10.1016/j .cvfa.2004.06.013.

Gulliksen, S. M., K. I. Lie, L. Sølverød, and O. Østerås. 2008. Risk factors associated with colostrum quality in Norwegian dairy cows. J. Dairy Sci. 91:704-712. https://doi.org/10.3168/jds.2007-0450.

Ha, N.-T., C. Drögemüller, C. Reimer, F. Schmitz-Hsu, R. M. Bruckmaier, H. Simianer, and J. J. Gross. 2017a. Liver transcriptome analysis reveals important factors involved in the metabolic adaptation of the transition cow. J. Dairy Sci. 100:9311-9323. https:// doi.org/10.3168/jds.2016-12454.

Ha, N.-T., J. J. Gross, A. R. Sharifi, M. Schlather, C. Drögemüller, U. Schnyder, F. Schmitz-Hsu, R. M. Bruckmaier, and H. Simianer. 2017b. Genetische Analyse der metabolischen Adaptation von Milchkühen in der Frühlaktation. Zuchtungskunde 89:48-60.

Ha, N.-T., J. J. Gross, H. A. van Dorland, J. Tetens, G. Thaller, M. Schlather, R. Bruckmaier, and H. Simianer. 2015. Gene-based mapping and pathway analysis of metabolic traits in dairy cows. PLoS One 10:e0122325. https://doi.org/10.1371/journal.pone .0122325

Ha, N.-T., A. R. Sharifi, J. Heise, M. Schlather, U. Schnyder, J. J. Gross, F. Schmitz-Hsu, R. M. Bruckmaier, and H. Simianer. 2017c. A reaction norm sire model to study the effect of metabolic challenge in early lactation on the functional longevity of dairy cows. J. Dairy Sci. 100:3742-3753. https://doi.org/10.3168/ jds.2016-12031.

Hachenberg, S., C. Weinkauf, S. Hiss, and H. Sauerwein. 2007. Evaluation of classification modes potentially suitable to identify meta- bolic stress in healthy dairy cows during the peripartal period. J. Anim. Sci. 85:1923-1932. https://doi.org/10.2527/jas.2006-480.

Hadley, G. L., C. A. Wolf, and S. B. Harsh. 2006. Dairy cattle culling patterns, explanations, and implications. J. Dairy Sci. 89:22862296. https://doi.org/10.3168/jds.S0022-0302(06)72300-1.

Harvatine, K. J., and D. E. Bauman. 2011. Characterization of the acute lactational response to trans-10, cis-12 conjugated linoleic acid. J. Dairy Sci. 94:6047-6056. https://doi.org/10.3168/jds.2011 -4657 .

Hayssen, V. 1993. Empirical and theoretical constraints on the evolution of lactation. J. Dairy Sci. 76:3213-3233. https://doi.org/10 .3168/jds.S0022-0302(93)77659-6.

Hoffmann, B., D. Schams, T. Gimenéz, M. L. Ender, C. Herrmann, and H. Karg. 1973. Changes of progesterone, total oestrogens, corticosteroids, prolactin and LH in bovine peripheral plasma around parturition with special reference to the effect of exogenous corticoids and a prolactin inhibitor respectively. Acta Endocrinol. (Copenh.) 73:385-395.

Hötger, K., H. M. Hammon, C. Weber, S. Görs, A. Tröscher, R. M. Bruckmaier, and C. C. Metges. 2013. Supplementation of conjugated linoleic acid in dairy cows reduces endogenous glucose production during early lactation. J. Dairy Sci. 96:2258-2270. https:/ /doi.org/10.3168/jds.2012-6127.

Huber, K., S. Dänicke, J. Rehage, H. Sauerwein, W. Otto, U. RolleKampczyk, and M. von Bergen. 2016. Metabotypes with properly functioning mitochondria and anti-inflammation predict extended productive life span in dairy cows. Sci. Rep. 6:24642. https://doi .org/10.1038/srep24642.

Ingvartsen, K. L. 2006. Feeding- and management-related diseases in the transition cow: Physiological adaptations around calving and strategies to reduce feeding-related diseases. Anim. Feed Sci. Technol. 126:175-213. https://doi.org/10.1016/j.anifeedsci.2005 .08 .003 .

Ingvartsen, K. L., R. J. Dewhurst, and N. C. Friggens. 2003. On the relationship between lactational performance and health: Is it yield or metabolic imbalance that cause production diseases in dairy cattle? A position paper. Livest. Prod. Sci. 83:277-308. https:// doi.org/10.1016/S0301-6226(03)00110-6.

Jaakson, H., P. Karis, K. Ling, A. Ilves-Luht, J. Samarütel, M. Henno, I. Jõudu, A. Waldmann, E. Reimann, P. Pärn, R. M. Bruckmaier, J. J. Gross, T. Kaart, M. Kass, and M. Ots. 2018. Adipose tissue insulin receptor and glucose transporter 4 expression, and blood glucose and insulin responses during glucose tolerance tests in transition Holstein cows with different body condition. J. Dairy Sci. 101:752-766. https://doi.org/10.3168/jds.2017-12877.

Kaufhold, J. N., H. M. Hammon, R. M. Bruckmaier, B. H. Breier, and J. W. Blum. 2000. Postprandial metabolism and endocrine status in veal calves fed at different frequencies. J. Dairy Sci. 83:24802490. https://doi.org/10.3168/jds.S0022-0302(00)75140-X.

Kessel, S., M. Stroehl, H. H. D. Meyer, S. Hiss, H. Sauerwein, F. J. Schwarz, and R. M. Bruckmaier. 2008. Individual variability in physiological adaptation to metabolic stress during early lactation in dairy cows kept under equal conditions. J. Anim. Sci. 86:29032912. https://doi.org/10.2527/jas.2008-1016.

Kesser, J., M. Korst, C. Koch, F. J. Romberg, J. Rehage, U. Müller, M. Schmicke, K. Eder, H. M. Hammon, H. Sadri, and H. Sauerwein. 2017. Different milk feeding intensities during the first 4 weeks of rearing dairy calves: Part 2: Effects on the metabolic and endocrine status during calfhood and around the first lactation. J. Dairy Sci. 100:3109-3125. https://doi.org/10.3168/jds.2016-11595.

Kessler, E. C., R. M. Bruckmaier, and J. J. Gross. 2014a. Milk production during the colostral period is not related to the later lactational performance in dairy cows. J. Dairy Sci. 97:2186-2192. https://doi.org/10.3168/jds.2013-7573.

Kessler, E. C., J. J. Gross, and R. M. Bruckmaier. 2013. Different adaptation of IGF-I and its IGFBPs in dairy cows during a negative energy balance in early lactation and a negative energy balance induced by feed restriction in mid lactation. Vet. Med. Czech. $58: 459-467$.

Kessler, E. C., J. J. Gross, R. M. Bruckmaier, and C. Albrecht. 2014b. Cholesterol metabolism, transport, and hepatic regulation in dairy 
cows during transition and early lactation. J. Dairy Sci. 97:54815490. https://doi.org/10.3168/jds.2014-7926.

Kessler, E. C., S. K. Wall, L. L. Hernandez, R. M. Bruckmaier, and J. J. Gross. 2018. Short communication: Circulating serotonin is related to the metabolic status and lactational performance at the onset of lactation in dairy cows. J. Dairy Sci. 101:11455-11460. https://doi.org/10.3168/jds.2018-14626.

Knight, C. H., and C. J. Wilde. 1993. Mammary cell changes during pregnancy and lactation. Livest. Prod. Sci. 35:3-19. https://doi .org/10.1016/0301-6226(93)90178-K.

Korst, M., C. Koch, J. Kesser, U. Müller, F. J. Romberg, J. Rehage, K. Eder, and H. Sauerwein. 2017. Different milk feeding intensities during the first 4 weeks of rearing in dairy calves: Part 1: Effects on performance and production from birth over the first lactation. J. Dairy Sci. 100:3096-3108. https://doi.org/10.3168/ jds.2016-11594.

Laeger, T., C. C. Metges, and B. Kuhla. 2010. Role of beta-hydroxybutyric acid in the central regulation of energy balance. Appetite 54:450-455. https://doi.org/10.1016/j.appet.2010.04.005.

Laffel, L. 1999. Ketone bodies: A review of physiology, pathophysiology and application of monitoring to diabetes. Diabetes Metab. Res. Rev. 15:412-426.

Langer, P. 2008. The phases of maternal investment in eutherian mammals. Zoology (Jena) 111:148-162. https://doi.org/10.1016/j.zool 2007.06.007.

Langer, P. 2009. Differences in the composition of colostrum and milk in eutherians reflect differences in immunoglobulin transfer. J. Mammal. 90:332-339. https://doi.org/10.1644/08-MAMM-A-071 .1.

Laporta, J., J. J. Gross, T. D. Crenshaw, R. M. Bruckmaier, and L. L. Hernandez. 2014. Short communication: Timing of first milking affects serotonin (5-HT) concentrations. J. Dairy Sci. 97:2944-2948. https://doi.org/10.3168/jds.2013-7336.

LeBlanc, S. 2010. Monitoring metabolic health of dairy cattle in the transition period. J. Reprod. Dev. 56(Suppl.):S29-S35.

Lefèvre, C. M., J. A. Sharp, and K. R. Nicholas. 2010. Evolution of lactation: Ancient origin and extreme adaptations of the lactation system. Annu. Rev. Genomics Hum. Genet. 11:219-238. https:// doi.org/10.1146/annurev-genom-082509-141806.

Levieux, D., and A. Ollier. 1999. Bovine immunoglobulin G, betalactoglobulin, alpha-lactalbumin and serum albumin in colostrum and milk during the early postpartum period. J. Dairy Res. $66: 421-430$.

Loor, J. J. 2010. Genomics of metabolic adaptations in the peripartal cow. Animal 4:1110-1139. https://doi.org/10.1017/ S1751731110000960.

Lucy, M. C., H. Jiang, and Y. Kobayashi. 2001. Changes in the somatotropic axis associated with the initiation of lactation. J. Dairy Sci. 84(E-Suppl.):E113-E119. https://doi.org/10.3168/jds.S0022 -0302(01)70205-6.

Lucy, M. C., G. A. Verkerk, B. E. Whyte, K. A. Macdonald, L. Burton, R. T. Cursons, J. R. Roche, and C. W. Holmes. 2009. Somatotropic axis components and nutrient partitioning in genetically diverse dairy cows managed under different feed allowances in a pasture system. J. Dairy Sci. 92:526-539. https://doi.org/10.3168/ jds.2008-1421.

Ma, L., K. L. Cook, D. E. Bauman, and K. J. Harvatine. 2015. Short communication: Milk fat depression induced by conjugated linoleic acid and a high-oil and low-fiber diet occurs equally across the day in Holstein cows. J. Dairy Sci. 98:1851-1855. https://doi.org/10 $.3168 /$ jds.2014-8614.

Mann, S., D. V. Nydam, A. Abuelo, F. A. Leal Yepes, T. R. Overton, and J. J. Wakshlag. 2016. Insulin signalling, inflammation, and lipolysis in subcutaneous adipose tissue of transition dairy cows either overfed energy during the prepartum period or fed a controlled-energy diet. J. Dairy Sci. 99:6737-6752. https://doi.org/10 .3168/jds.2016-10969.

Mattmiller, S. A., C. M. Corl, J. C. Gandy, J. J. Loor, and L. M. Sordillo. 2011. Glucose transporter and hypoxia-associated gene expression in the mammary gland of transition dairy cattle. J. Dairy Sci. 94:2912-2922. https://doi.org/10.3168/jds.2010-3936.
McArt, J. A., D. V. Nydam, and G. R. Oetzel. 2012. Epidemiology of subclinical ketosis in early lactation dairy cattle. J. Dairy Sci. 95:5056-5066. https://doi.org/10.3168/jds.2012-5443.

Mertens, D. R., and R. G. Dado. 1993. System of equations for fulfilling net energy and absorbed protein requirements for milk component production. J. Dairy Sci. 76:3464-3478. https://doi.org/10 .3168/jds.S0022-0302(93)77686-9.

Morin, D. E., P. D. Constable, F. P. Maunsell, and G. C. McCoy. 2001. Factors associated with colostral specific gravity in dairy cows. J. Dairy Sci. 84:937-943. https://doi.org/10.3168/jds.S0022 $-0302(01) 74551-1$

Morin, D. E., S. V. Nelson, E. D. Reid, D. W. Nagy, G. E. Dahl, and P. D. Constable. 2010. Effect of colostral volume, interval between calving and first milking, and photoperiod on colostral IgG concentrations in dairy cows. J. Am. Vet. Med. Assoc. 237:420-428. https://doi.org/10.2460/javma.237.4.420.

Morrill, K. M., E. Conrad, J. Polo, A. Lago, J. Campbell, J. Quigley, and H. Tyler. 2012. Estimate of colostral immunoglobulin G concentration using refractometry without or with caprylic acid fractionation. J. Dairy Sci. 95:3987-3996. https://doi.org/10.3168/jds .2011-5104.

Mulligan, F. J., and M. L. Doherty. 2008. Production diseases of the transition cow. Vet. J. 176:3-9. https://doi.org/10.1016/j.tvjl.2007 .12 .018 .

Oftedal, O. T. 2012. The evolution of milk secretion and its ancient origins. Animal 6:355-368. https://doi.org/10.1017/ S1751731111001935.

Oliveira, R. C., R. S. Pralle, L. C. de Resende, C. H. P. C. Nova, V. Caprarulo, J. A. Jendza, A. Troescher, and H. M. White. 2018. Prepartum supplementation of conjugated linoleic acids (CLA) increased milk energy output and decreased serum fatty acids and $\beta$-hydroxybutyrate in early lactation dairy cows. PLoS One 13:e197733. https://doi.org/10.1371/journal.pone.0197733.

Ollier, S., X. Zhao, and P. Lacasse. 2015. Effects of feed restriction and prolactin-release inhibition at drying-off on susceptibility to new intramammary infection in cows. J. Dairy Sci. 98:221-228. https:/ /doi.org/10.3168/jds.2014-8426

Ospina, P. A., D. V. Nydam, T. Stokol, and T. R. Overton. 2010. Evaluation of nonesterified fatty acids and beta-hydroxybutyrate in transition dairy cattle in the northeastern United States: Critical thresholds for prediction of clinical diseases. J. Dairy Sci. 93:546-554. https://doi.org/10.3168/jds.2009-2277.

Overton, T. R., and M. R. Waldron. 2004. Nutritional management of transition dairy cows: Strategies to optimize metabolic health. J. Dairy Sci. 87(E-Suppl.):E105-E119. https://doi.org/10.3168/jds .S0022-0302(04)70066-1.

Pezeshki, A., A. V. Capuco, B. De Spiegeleer, L. Peelman, M. Stevens, R. J. Collier, and C. Burvenich. 2010. An integrated view on how the management of the dry period length of lactating cows could affect mammary biology and defence. J. Anim. Physiol. Anim. Nutr. (Berl.) 94:e7-e30. https://doi.org/10.1111/j.1439-0396.2010 .00991.x.

Pritchard, T., M. Coffey, R. Mrode, and E. Wall. 2013. Understanding the genetics of survival in dairy cows. J. Dairy Sci. 96:3296-3309. https://doi.org/10.3168/jds.2012-6219.

Pritchett, L. C., C. C. Gay, T. E. Besser, and D. D. Hancock. 1991. Management and production factors influencing immunoglobulin G1 concentration in colostrum from Holstein cows. J. Dairy Sci. 74:2336-2341. https://doi.org/10.3168/jds.S0022-0302(91)78406 $-3$.

Pryce, J. E., T. T. T. Nguyen, M. Axford, G. Nieuwhof, and M. Shaffer. 2018. Symposium review: Building a better cow-The Australian experience and future perspectives. J. Dairy Sci. 101:37023713. https://doi.org/10.3168/jds.2017-13377.

Purup, S., M. Vestergaard, M. S. Weber, K. Plaut, R. M. Akers, and K. Sejrsen. 2000. Local regulation of pubertal mammary growth in heifers. J. Anim. Sci. 78(Suppl. 3):36-47. https://doi.org/10.2527/ 2000.78suppl_336x.

Quigley, J. D., A. Lago, C. Chapman, P. Erickson, and J. Polo. 2013. Evaluation of the Brix refractometer to estimate immunoglobulin 
G concentration in bovine colostrum. J. Dairy Sci. 96:1148-1155. https://doi.org/10.3168/jds.2012-5823.

Raboisson, D., M. Mounié, and E. Maigné. 2014. Diseases, reproductive performance, and changes in milk production associated with subclinical ketosis in dairy cows: A meta-analysis and review. J. Dairy Sci. 97:7547-7563. https://doi.org/10.3168/jds.2014-8237.

Raboisson, D., P. Trillat, and C. Cahuzac. 2016. Failure of passive immune transfer in calves: A meta-analysis on the consequences and assessment of the economic impact. PLoS One 11:e0150452. https: //doi.org/10.1371/journal.pone.0150452.

Rajala-Schultz, P. J., J. S. Hogan, and K. L. Smith. 2005. Short communication: Association between milk yield at dry-off and probability of intramammary infections at calving. J. Dairy Sci. 88:577-579. https://doi.org/10.3168/jds.S0022-0302(05)72720-X.

Renaville, R., M. Hammadi, and D. Portetelle. 2002. Role of somatotropic axis in the mammalian metabolism. Domest. Anim. Endocrinol. 23:351-360.

Rocco, S. M., and J. P. McNamara. 2013. Regulation of bovine adipose tissue metabolism during lactation. 7. Metabolism and gene expression as a function of genetic merit and dietary energy intake. J. Dairy Sci. 96:3108-3119. https://doi.org/10.3168/jds.2012-6097.

Roche, J. R., N. C. Friggens, J. K. Kay, M. W. Fisher, K. J. Stafford, and D. P. Berry. 2009. Invited review: Body condition score and its association with dairy cow productivity, health, and welfare. J. Dairy Sci. 92:5769-5801. https://doi.org/10.3168/jds.2009-2431.

Rojas-Morales, P., E. Tapia, and J. Pedraza-Chaverri. 2016. $\beta$-Hydroxybutyrate: A signaling metabolite in starvation response? Cell. Signal. 28:917-923. https://doi.org/10.1016/j.cellsig.2016.04 .005 .

Ruderman, N. B., and M. N. Goodman. 1973. Regulation of ketone body metabolism in skeletal muscle. Am. J. Physiol. 224:13911397. https://doi.org/10.1152/ajplegacy.1973.224.6.1391.

Rutherford, A. J., G. Oikonomou, and R. F. Smith. 2016. The effect of subclinical ketosis on activity at estrus and reproductive performance in dairy cattle. J. Dairy Sci. 99:4808-4815. https://doi.org/ $10.3168 /$ jds. $2015-10154$.

Samarütel, J., C. R. Baumrucker, J. J. Gross, C. D. Dechow, and R. M. Bruckmaier. 2016. Quarter variation and correlations of colostrum albumin, immunoglobulin G1 and G2 in dairy cows. J. Dairy Res. 83:209-218. https://doi.org/10.1017/S0022029916000091.

Sartin, J. L., K. A. Cummins, R. J. Kemppainen, D. N. Marple, C. H. Rahe, and J. C. Williams. 1985. Glucagon, insulin, and growth hormone responses to glucose infusion in lactating dairy cows. Am. J. Physiol. 248:E108-E114. https://doi.org/10.1152/ajpendo.1985 .248.1.E108.

Schäff, C. T., J. Gruse, J. Maciej, M. Mielenz, E. Wirthgen, A. Hoeflich, M. Schmicke, R. Pfuhl, P. Jawor, T. Stefaniak, and H. M. Hammon. 2016. Effects of feeding milk replacer ad libitum or in restricted amounts for the first five weeks of life on the growth, metabolic adaptation, and immune status of newborn calves. PLoS One 11:e0168974. https://doi.org/10.1371/journal.pone.0168974.

Sejrsen, K., J. T. Huber, H. A. Tucker, and R. M. Akers. 1982. Influence of nutrition of mammary development in pre- and postpubertal heifers. J. Dairy Sci. 65:793-800.

Sejrsen, K., and S. Purup. 1997. Influence of prepubertal feeding level on milk yield potential of dairy heifers: A review. J. Anim. Sci. 75:828-835. https://doi.org/10.2527/1997.753828x.

Singh, S. P., S. Häussler, J. J. Gross, F. J. Schwarz, R. M. Bruckmaier, and H. Sauerwein. 2014. Short communication: Circulating and milk adiponectin change differently during energy deficiency at different stages of lactation in dairy cows. J. Dairy Sci. 97:15351542. https://doi.org/10.3168/jds.2013-7598.

Skibiel, A. L., L. M. Downing, T. J. Orr, and W. R. Hood. 2013. The evolution of the nutrient composition of mammalian milks. J. Anim. Ecol. 82:1254-1264. https://doi.org/10.1111/1365-2656 .12095 .

Sniffen, C. J., R. W. Beverly, C. S. Mooney, M. B. Roe, A. L. Skidmore, and J. R. Black. 1993. Nutrient requirements versus supply in the dairy cow: Strategies to account for variability. J. Dairy Sci. 76:3160-3178. https://doi.org/10.3168/jds.S0022-0302(93)77655 $-9$.
Sordillo, L. M., G. A. Contreras, and S. L. Aitken. 2009. Metabolic factors affecting the inflammatory response of periparturient dairy cows. Anim. Health Res. Rev. 10:53-63. https://doi.org/10.1017/ S1466252309990016.

Stott, G. H., D. B. Marx, B. E. Menefee, and G. T. Nightengale. 1979. Colostral immunoglobulin transfer in calves I. Period of absorption. J. Dairy Sci. 62:1632-1638. https://doi.org/10.3168/jds .S0022-0302(79)83472-4.

Suriyasathaporn, W., A. J. Daemen, E. N. Noordhuizen-Stassen, S. J. Dieleman, M. Nielen, and Y. H. Schukken. 1999. Beta-hydroxybutyrate levels in peripheral blood and ketone bodies supplemented in culture media affect the in vitro chemotaxis of bovine leukocytes. Vet. Immunol. Immunopathol. 68:177-186.

Suthar, V. S., J. Canelas-Raposo, A. Deniz, and W. Heuwieser. 2013. Prevalence of subclinical ketosis and relationships with postpartum diseases in European dairy cows. J. Dairy Sci. 96:2925-2938. https://doi.org/10.3168/jds.2012-6035.

Te Velde, H., N. Aarts, and C. Van Woerkum. 2002. Dealing with ambivalence: Farmers' and consumers' perceptions of animal welfare in livestock breeding. J. Agric. Environ. Ethics 15:203-219. https: //doi.org/10.1023/A:1015012403331.

Trevisi, E., M. Amadori, S. Cogrossi, E. Razzuoli, and G. Bertoni. 2012. Metabolic stress and inflammatory response in high-yielding, periparturient dairy cows. Res. Vet. Sci. 93:695-704. https://doi .org/10.1016/j.rvsc.2011.11.008.

Han van der Kolk, J. H., J. J. Gross, V. Gerber, and R. M. Bruckmaier. 2017. Disturbed bovine mitochondrial lipid metabolism: A review. Vet. Q. 37:262-273. https://doi.org/10.1080/01652176 .2017.1354561.

van Hoeij, R. J., J. Dijkstra, R. M. Bruckmaier, J. J. Gross, T. J. G. M. Lam, G. J. Remmelink, B. Kemp, and A. T. M. van Knegsel. 2017a. The effect of dry period length and postpartum level of concentrate on energy balance and plasma metabolites of dairy cows across the dry period and in early lactation. J. Dairy Sci. 100:5863-5879. https://doi.org/10.3168/jds.2016-11703.

van Hoeij, R. J., J. Dijkstra, R. M. Bruckmaier, J. J. Gross, T. J. G. M. Lam, G. J. Remmelink, B. Kemp, and A. T. M. van Knegsel. 2017b. Consequences of dietary energy source and energy level on energy balance, lactogenic hormones, and lactation curve characteristics of cows after a short or omitted dry period. J. Dairy Sci. 100:8544-8564. https://doi.org/10.3168/jds.2017-12855.

van Knegsel, A. T., S. G. van der Drift, J. Cermáková, and B. Kemp. 2013. Effects of shortening the dry period of dairy cows on milk production, energy balance, health, and fertility: A systematic review. Vet. J. 198:707-713. https://doi.org/10.1016/j.tvjl.2013.10 .005 .

van Knegsel, A. T. M., H. M. Hammon, U. Bernabucci, G. Bertoni, R. M. Bruckmaier, R. M. A. Goselink, J. J. Gross, B. Kuhla, C. C. Metges, H. K. Parmentier, E. Trevisi, A. Tröscher, and A. M. van Vuuren. 2014. Metabolic adaptation during early lactation: Key to cow health, longevity and a sustainable dairy production chain. CAB Rev. 9:002. https://doi.org/10.1079/PAVSNNR20149002.

Vernay, M. C., O. Wellnitz, L. Kreipe, H. A. van Dorland, and R. M. Bruckmaier. 2012. Local and systemic response to intramammary lipopolysaccharide challenge during long-term manipulated plasma glucose and insulin concentrations in dairy cows. J. Dairy Sci. 95:2540-2549. https://doi.org/10.3168/jds.2011-5188.

Verweij, J. J., A. P. Koets, and S. W. Eisenberg. 2014. Effect of continuous milking on immunoglobulin concentrations in bovine colostrum. Vet. Immunol. Immunopathol. 160:225-229. https://doi .org/10.1016/j.vetimm.2014.05.008.

von Keyserlingk, M. A., N. P. Martin, E. Kebreab, K. F. Knowlton, R. J. Grant, M. Stephenson, C. J. Sniffen, J. P. Harner III, A. D. Wright, and S. I. Smith. 2013. Invited review: Sustainability of the US dairy industry. J. Dairy Sci. 96:5405-5425. https://doi.org/10 $.3168 /$ jds.2012-6354.

Wall, S. K., J. J. Gross, E. C. Kessler, K. Villez, and R. M. Bruckmaier. 2015. Blood-derived proteins in milk at start of lactation: Indicators of active or passive transfer. J. Dairy Sci. 98:7748-7756. https://doi.org/10.3168/jds.2015-9440. 
Wathes, D. C. 2012. Mechanisms linking metabolic status and disease with reproductive outcome in the dairy cow. Reprod. Domest. Anim. 47(Suppl. 4):304-312. https://doi.org/10.1111/j.1439-0531 2012.02090.x.

Wathes, D. C., J. S. Brickell, N. E. Bourne, A. Swali, and Z. Cheng. 2008. Factors influencing heifer survival and fertility on commercial dairy farms. Animal 2:1135-1143. https://doi.org/10.1017/ S1751731108002322.

Watters, R. D., J. N. Guenther, A. E. Brickner, R. R. Rastani, P. M. Crump, P. W. Clark, and R. R. Grummer. 2008. Effects of dry period length on milk production and health of dairy cattle. J. Dairy Sci. 91:2595-2603. https://doi.org/10.3168/jds.2007-0615.

Weary, D. M., B. A. Ventura, and M. A. G. von Keyserlingk. 2016. Societal views and animal welfare science: Understanding why the modified cage may fail and other stories. Animal 10:309-317. https://doi.org/10.1017/S1751731115001160.

Weary, D. M., and M. A. G. von Keyserlingk. 2017. Public concerns about dairy-cow welfare: How should the industry respond? Anim. Prod. Sci. 57:1201-1209. https://doi.org/10.1071/AN16680.

Weaver, D. M., J. W. Tyler, D. C. VanMetre, D. E. Hostetler, and G. M. Barrington. 2000. Passive transfer of colostral immunoglobulins in calves. J. Vet. Intern. Med. 14:569-577.

Zarrin, M., L. Grossen-Rösti, R. M. Bruckmaier, and J. J. Gross. 2017. Elevation of blood $\beta$-hydroxybutyrate concentration affects glucose metabolism in dairy cows before and after parturition. J. Dairy Sci. 100:2323-2333. https://doi.org/10.3168/jds.2016-11714.
Zarrin, M., O. Wellnitz, H. A. van Dorland, and R. M. Bruckmaier. 2014a. Induced hyperketonemia affects the mammary immune response during lipopolysaccharide challenge in dairy cows. J. Dairy Sci. 97:330-339. https://doi.org/10.3168/jds.2013-7222.

Zarrin, M., O. Wellnitz, H. A. van Dorland, J. J. Gross, and R. M. Bruckmaier. 2014b. Hyperketonemia during lipopolysaccharide-induced mastitis affects systemic and local intramammary metabolism in dairy cows. J. Dairy Sci. 97:3531-3541. https://doi.org/10 3168/jds.2013-7480.

Zbinden, R. S., M. Falk, A. Münger, F. Dohme-Meier, H. A. van Dorland, R. M. Bruckmaier, and J. J. Gross. 2017. Metabolic load in dairy cows kept in herbage based feeding systems and suitability of potential markers for compromised well-being. J. Anim. Physiol. Anim. Nutr. (Berl.) 101:767-778. https://doi.org/10.1111/jpn .12498 .

Zhao, F.-Q., and A. F. Keating. 2007a. Functional properties and genomics of glucose transporters. Curr. Genomics 8:113-128.

Zhao, F.-Q., and A. F. Keating. 2007b. Expression and regulation of glucose transporters in the bovine mammary gland. J. Dairy Sci. 90(E-Suppl.):E76-E86. https://doi.org/10.3168/jds.2006-470.

Zhou, H., X. Song, M. Briggs, B. Violand, W. Salsgiver, E. A. Gulve, and Y. Luo. 2005. Adiponectin represses gluconeogenesis independent of insulin in hepatocytes. Biochem. Biophys. Res. Commun. 338:793-799. https://doi.org/10.1016/j.bbrc.2005.10.007. 